\title{
Interactive comment on "Validation of the dynamic wake meandering model with respect to loads and power production" by Inga Reinwardt et al.
}

Inga Reinwardt et al.

inga.reinwardt@haw-hamburg.de

Received and published: 4 February 2021

We are very thankful for your valuable comments on the paper. The authors responses to all comments are attached.

Please also note the supplement to this comment:

https://wes.copernicus.org/preprints/wes-2020-126/wes-2020-126-AC2-

supplement.pdf

Interactive comment on Wind Energ. Sci. Discuss., https://doi.org/10.5194/wes-2020-126, 2020. 